\title{
Dimensions of Epistemology and the Case for Africa's Indigenous Ways of Knowing
}

\author{
Amaechi Udefi ${ }^{*}$
}

\section{Abstract}

African philosophical practice has taken a new turn since it survived the large scale problems and debates which characterized its early beginnings in an African environment and intellectual community. The metaphilosophical issues then concerned about its status, relevance and methodology appropriate or usable for doing it. Although the issues that troubled African philosophers then may have subsided, yet some of them have and are still expressing reservations on the possibility of having Africa's indigenous ways of knowing, just as they deny the possibility of 'African physics' or 'African arithmetic'. Paulin Hountondji, a leading African philosopher, is reputed for denying African traditional thought as philosophy, which he prefers to type as ethnophilosophy, simply because it thrives on orality and other ethnographical materials like proverbs, parables, folklores, fables, songs etc. For him, the piece, at best can qualify as ethnographical or anthropological monographs as opposed to philosophical work which relies on written texts and documentation on the basis of which "theoretical knowledge and significant intellectual exchange and innovation can" be achieved in Africa. Hountondji's position is, to say the least, exclusionist, since it denies and debars African modes of thought and heritage a position in the on-going philosophical conversation or discourse.

* Department of Philosophy, University of Ibadan, Nigeria; amy4ibe@yahoo.com 
The paper shares Hountondji's vision of adoption of an attitude of critical, scientific and skeptical orientation in African societies. However, it rejects the views of Hountondji and other scholars who deny African intellectual and cognitive systems and argues that their position rests on one sided conception or dimension of epistemology. The other intention of the paper is to show that philosophical practice is as old as the history of mankind in Africa, though Hountondj has expressed the view that philosophy as an academic discipline started in African Universities only in the 1960's and 1970's.

Keywords: Epistemology, African Philosophy, Ethnophilosophy, Indigenous Knowledge, Culture.

\section{Two Senses of the Word Epistemology}

As it is familiar, the introduction and establishment of African Philosophy as part of the curriculum in Nigeria's higher education was marked or preceded by a long debate centering but not exclusively on its methodology and status as an academic discipline. As the debate continued, African philosophers and scholars were torn into different camps. On the one hand, there were some who took a skeptical position arguing that African philosophy was still in the making. On the other, some took a cultural position and were prepared to concede that African philosophy was continuous with African culture.

Paulin Hountondji, one of leading African philosophers typed the position of the latter group as ethnophilosophical, which he takes to be an attempt to "define a specific African philosophy, a worldview common to all Africans, past, present and future, a collective, immutable system of thought in eternal apposition to that of Europe"1. This way of understanding African philosophy, according to Hountondji, prompts some African philosophers to see it as a matter of duty to "reconstruct the thought of his forefathers, the collective Weltanschauung of his people" 2 . He avers that ethnophilosophy has as its main objective;

...to reconstruct a particular Weltanschauung, a specific world-view commonly attributed to all Africans, abstracted from history and change and 
moreover, philosophical through an interpretation of the customs and traditions, proverbs and institutions in short, various data-concerning the cultural life of African people 3 .

Hountondji would not have been worried by the anthropologisation of African philosophy and this kind of scholarship if it had identified itself as a form of cultural anthropology," and not, as its proponents would want us to believe, as representing African Philosophy and as the proper methodological rendering of African philosophies'4. The assumption here is that philosophy cannot exist as 'implicit,' 'collective', and 'communal thought,' which characterizes all Africans. Neither can philosophy be masked in the form of poems, myth, legends, etc, since these, according to Hountondji, are "artistic literature as distinct from scientific literature."5 Hountondji, like the members of the Analytic African philosophy, understands philosophy in the active sense that it is a rational and critical study of which argumentation and clarification are its essential hallmarks," persistently "questioning the untiring dialectic that accidentally produces systems and then projects them towards a horizon of fresh truths."6 The key points in Hountondji's denunciation of ethnophilosophy include;

i. Orality

ii. Myth of unanimity

iii. Collective or communal thought as opposed to individual thought

iv. Unconscious, spontaneous and implicit world-view

v. Cultural uniqueness

Based on his uncompromising acceptance of philosophy as defined or understood in a Western context, it is natural that he would reject as tribal world-view, terms like Igbo philosophy, Yoruba philosophy, Dogon philosophy, Akan philosophy etc. In the same manner, he would discountenance the idea of African theory of knowledge for the same reasons and arguments, even though African philosophers and scholars in and around Africa have sufficiently demonstrated with argumentative skills the existence of such philosophy and epistemology as found amongst indigenous African people. Perhaps, an explication of the two senses of the 
word 'epistemology' would dispel Hountondji's anxiety and vexation about the potentials and reality of ethnophilosophy and/or collective epistemology which is the concern of this essay.

\subsection{Ordinary or Broad Sense of Epistemology}

Epistemology or theory of knowledge is that branch of philosophy, which studies the nature of knowledge especially the question of how we know what we claim to know and the extent to which we know it.7 But epistemology is susceptible to another sense, where it is taken to mean the communal beliefs of a people because any group of human beings will certainly have to have some world outlook, that is, some general conceptions about the world in which they live and themselves both as individuals and as members of society. ${ }^{8}$

Indeed in talking about traditional African philosophy, 'we do not need to assume that there is any kind of metaphysical or mythic unity among Africans with respect to their conceptions of nature, the human, existence, society, etc. It is also not necessary to suggest that these conceptions are unique to them. We do not have to make any of these suggestions because of the diversity of the cultures and traditions in Africa and the possibility that these cultures and traditions might share some of their essential attributes with those of other societies. The point however, is that in spite of the diversity, we can still identify some deep underlying affinities running through the various African cultures and traditions in virtue of which we can establish their unity'. The point we are making here is well stated by Anyanwu when he says:

...a skeptic may doubt whether what I have described as the basic assumptions of African culture refer to all black African cultures or to specific or particular cultures of certain groups of people in Africa. I would say that it makes no difference whether one speaks about the philosophy of a particular ethnic group in Africa or the philosophy of African culture in general,...The underlying principles inherent in all African cultures are applicable in any form in which one may formulate African (traditional) philosophy ${ }^{9}$ 
Thus on the basis of this illuminating insight by an African philosopher, we can say that there is a certain underlying identity even in the face of plurality of African traditions and heritage. ${ }^{10}$ Let us therefore admit that there is a traditional African philosophy. This philosophy is certainly not a stock of metaphysical notions common to all Africans. Rather, it is 'an abstraction standing for those interrelated conceptions of nature, human, society, morality etc.

It is important here to distinguish between objective and subjective, or the material conditions that enable one or other philosophy and the vehicles for its expression to come into being. This point is taken by Joseph Dietzgen, when he writes:

Just as the reformulation was conditioned by the material base of the 16th century, so the theory of human intellectual operations just like the discovery of the electric telegraph is conditioned by the material base of the 19th century. Accordingly the contents of this tract are not the product of an individual mind, rather they are a plant born on historical soil... ${ }^{11}$

What emerges from this would be, that there is no apparent link of necessity between the existence of philosophy and the effort of the individual since every philosophy that finds expression after, as it were, a period of gestation is always informed through the channel of one or more individuals. The vital point in a debate about the existence or non-existence of mode of thought cannot therefore be the emergence of an individual philosopher. Rather it must be what Dietzgen has rightly called 'the material base.' The point here is that philosophy like history in general, cannot be conceived as the work of geniuses. For there is abundant evidence in African traditional thought to show that indigenous thinkers are capable of reflective philosophical thinking and on the basis of which we can say that such a world-view is characteristic of a people's communal outlook upon the universe. It would be said then that any attempt to reject this in preference to 'the theoretical effort of the individual' is to say the least an intellectual fraud appropriating the fruits of the work, both manual and intellectual of the mass of the people. ${ }^{12}$ 
These scholars, especially Hountondji, who reject African traditional thought because according to them, it is a collective philosophy which is known by every Tom, Dick and Harry in the community failed because it ignored the relevance and impact of culture on the reflections of the individual thinker. Because they believe that philosophizing is a wholly individualistic affair, they also fail to realize that their so-called individual thinker must draw as his/her raw data the communal ideas and belief systems preponderant in his community. In other words, we cannot possibly divorce the philosophy of an individual thinker from the ideas current among the people, because such philosophy of the individual thinker is rooted in the beliefs and assumptions of the culture. Here, the term culture is taken from its Latin roots, cultura meaning cultivating or tilling the land. It was taken by Cicero and others as the cultivation of the soul or mind since the human spirit will not achieve its proper result if it is not trained or educated. ${ }^{13}$ However, we shall define culture following E. B. Tylor, to be "that complex whole which includes knowledge, belief, art, morals, law, customs and any other capabilities and habits acquired by the human as a member of society."14 It is argued that we are justified in saying that Greek philosophy and British philosophy refer to the ideas of Socrates, Plato and Locke, Berkeley receptively simply because such philosophy has its roots or basis in the culture, traditions and mentalities of the societies of these people.

The point being made so far is that philosophy (epistemology) is the product of a culture because it is inconceivable to say that a culture can exist without those elements of thought that are shared in common. Hence, we can say that all individualized philosophies stem from the general experience and problem confronting a particular people in a given cultural environment. On this Anyanwu says:

The philosophies of individuals are still subordinate to public philosophy, and in the ultimate analysis public (collective) philosophy. ${ }^{15}$

In order to corroborate the point we are canvassing here, it may be instructive to examine, however sketchily, some of the philosophical doctrines of some individual thinkers in the Western philosophical tradition to see how they appropriated the dominant 6 
ideas of their culture to formulate their doctrines. In ancient philosophy both Thales, Anaximander and Anaximenes were credited for explaining natural phenomena in purely systematic and scientific terms, thereby carrying, in a manner of speaking, a kind of 'Copernican Revolution' that changed the thought pattern of the ancients from interpreting natural phenomena in terms of supernatural and human agencies to doing so in scientific and nonhuman agencies. It is important to note that the main preoccupation of these philosophers was to discover the ultimate principles that underlie the various things in the physical world. It is argued that Thales, for example, founded all things in the world on 'water.' Also, it is contended that Aristotle is known for saying that the idea that water subsists all things in the universe was common in the mythological traditions of the Greeks and the peoples with whom they come in contact. ${ }^{16}$ The issue here is that the notion of water and the beliefs and practices associated with it were already embodied in the Greeks' conception of natural phenomena. The philosopher merely draws for his analysis the ideas or raw data embedded in the communal world outlook of his people.

As a matter of fact, the minds of the philosophers are not like 'tabula rasa' (in Locke's phrase) where ideas are imprinted, but are already furnished with the ideas, beliefs, and thoughts of their society. Based on this, we can argue that philosophical discussion in any given epoch is determined by a set of assumptions which are the groundwork of current conceptions shared by all men of a given culture. ${ }^{17}$ Thus, it can be argued that Greek philosophy or any other arises out of the minds of the people and is in fact a component part of that culture. This fact is obvious when we consider what Bertrand Russell says:

My purpose is to exhibit philosophy as an integral part of social and political life, not as the isolated speculations of remarkable individuals. 18 


\subsection{Technical or Strict Sense of Epistemology}

What we attempt here is to examine epistemology in its strict or technical sense with a view to show that both the broad or general and narrow or technical sense shade into each other in many forms, as well as unraveling some of the pitfalls associated with the technical sense of the term. The word 'epistemology' is a compound Greek word formed from two simple parts, 'episteme' which means 'knowledge' and 'logos' which connotes 'theory'. Hence, epistemology is referred to as 'theory of knowledge.'

Even though epistemology embraces a variety of concepts and issues, its central questions that agitated the minds of philosophers have remained the same. These include, what are the criteria of knowledge? How does one know or come to know anything at all? And how does one know that one knows anything? These questions, we believe, serve as an invitation to analyze the status and nature of our knowledge claim; the validation of our cognitive experience; and the relationship between our cognitive experience and the various objects in the world. This is what Michael Williams intends when he says that epistemology is concerned with the nature or structure of the justification of our most important beliefs, our belief in the existence of the physical world. ${ }^{19}$

Now apart from the above questions, there is even a larger question which is: why a theory of knowledge? that is, is it necessary to have a theory of knowledge? The other problems that border on the above questions, are the problems of what we understand by the term Knowledge, and what is it that deserves the title of knowledge .${ }^{20}$ It is argued that the answers to these problems can be achieved only by those that are equipped with the techniques or methodology appropriate for the discovery of the truth in them. The same thing can be said even of a specifically knowledge claim made by someone on the street because it is only those who have the relevant facts that can make the necessary inferences and deductions. However, there is an exception here, that is, a philosopher, because of his understanding of what constitutes knowledge, what in general could count as knowledge, can assert that some particular claim purported to be a knowledge claim does not qualify as knowledge in the real sense of the word. The reasons 8 
for the philosopher's discountenance of such claim could be that the conditions necessary for any claim to qualify as a genuine claim to knowledge are not met and it is possible that the person making such claim simply does not have sufficient grounds for his claim which, in turn, may vitiate such claim from being true. The point then is that any claim to knowledge, if it is to be a valid claim, presupposes a prior satisfaction of the conditions concerning grounds, truth, meaning etc. Thus, the task of the philosopher, concerned with the theory of knowledge, is to investigate and elucidate, in a practical manner, the conditions and concept of knowledge.

The word 'know' is slippery, as it is complex and sometimes technical and philosophers have continued to grapple with its exact meaning. Whereas some philosophers describe the word as psychological or propositional attitudes towards statements or a state of affairs, others reject and instead claim that it has distinctive tone as a private mental state that intuitively distinguishes it from the other psychological attitudes. ${ }^{21}$ For these people, such statements as 'I know $\mathrm{x}$ : will then refer to only that distinctive state of mind at that particular time. But its ordinary English usage tends to suggest that the word is commonly used in a dispositional or behavioral sense. On this, H. H. Price writes;

Now in ordinary everyday English the verb 'to know' generally used in a dispositional sense: not quite invariably perhaps, but certainly the dispositional use of it is by far the most common. ${ }^{22}$

Although, we shall not wish to enter into any controversy about the definition of the word here, we shall simply assert that whenever we talk of knowledge or the ordinary English verb 'to know' in epistemology,23 what we are aiming at is the sense in which a person knows that something is the case (knowing that or propositional knowledge), or the sense in which a person could be said to be acquainted with a state of affairs (knowledge by acquaintance). Such cases include, for example, the situation where a person claims to know that the atomic weight of gold is 197.2; or that A. J. Ayer is the author of The Problem of Knowledge, we believe that this sense of knowing entitles someone to talk of knowledge as being a sub-set of belief. Even, at that, the way we justify different 
claims to knowledge differs; hence the justification of the claim that a person knows that the atomic weight of gold is 197.2 is quite different from the justification required to prove the truth of the claim that A.J. Ayer is the author of The Problem of Knowledge. Now if this is accepted, then what justification do we have to say that they fall under the same concept? To answer this will imply also our knowledge or understanding of certain similarities they share especially in the ordinary usage. So this seems to be one of the sources of the philosophical importance of trying to find an adequate definition of knowledge, that is, a definition that could provide satisfactory criteria for assessing certain claims to knowledge. ${ }^{24}$

\section{Interconnections between the Broad and Strict Senses of Epistemology}

Like we stated above, the distinction between the broad and strict or narrow senses of philosophy is akin to those between 'critical' and 'collective' epistemology. Hence, the explication of one can be used to understand the other since epistemology is a core branch of philosophy. Some philosophers and scholars have made postulations alluding to the distinction between the broad and strict senses of the terms, 'philosophy,' 'epistemology.' Witness, for instance, F. C. Copleston's distinction between broadfield and 'second-order' philosophy25; Claude Sumner's 'broad' and 'narrow' philosophy26; D. A. Masolo's 'ordinary sense' and 'second sense' philosophy ${ }^{27}$. What is clear in all these two senses of philosophy (epistemology) is that these philosophers do not take them as autonomous and as existing independently of each other. For them, however, both overlap and shade into each other in a complementary manner.

The symbiotic relationship, as it were between the two senses or philosophy and/for epistemology is well expressed by Sumner when he argues that;

Philosophy in a broad sense is still philosophy. 'In this way, he justifies using the words Ethiopian Philosophy in the titles of his books '... He sees his own distinction between broad and narrow 
philosophy to be a bridge or compromise between Western version of philosophy and what is needed to include African wisdom traditions within the field of philosophy, thus making the definition more universal rather than narrowly European ${ }^{28}$.

Now, it was adumbrated above that Hountondji and some members of the analytic African philosophy movement have shown how traditional African thought cannot and should not constitute African philosophy. Hountondji, it should be recalled, in his seminal work, African Philosophy Myth and Reality, made a distinction between what he calls 'popular' and 'strict' senses of philosophy. The former, according to him, refers to "wisdom, individual or collective, which is made of coherent principles and meant to guide daily action." However in the strict sense, Hountondji argues that it cannot be spontaneous or collective philosophy, but is based on the scientific model of free discussion during which hypotheses are tested ${ }^{29}$.

Also, Kwasi Wiredu, a member of the analytic school of African philosophy may not be contemptuous to traditional African thought, as Hountondji, yet he (Wiredu) did not conceal his "colonized" version of philosophy that accepted Western definitions instead of creating African definitions of philosophy," in Sumner's phrase ${ }^{30}$. On traditional African Philosophy, Wiredu has this to say;

If African philosophy means Traditional African philosophy as surprisingly many people seem to think, then we can forget any pretence of modern philosophizing. In most parts of Africa, we would have, in that case, to abstain from such disciplines as symbolic logic and its philosophical interpretations, the philosophy of mathematics and of the natural and social sciences, the theory of knowledge associated with the foregoing disciplines and the moral, political and social philosophy which has arisen as a response to the needs of modern times... ${ }^{31}$ [author's italics] 
According to Olusegun Oladipo, Wiredu's rejection of the equation of African Philosophy with African folk thought is informed by two considerations namely; 'practical and theoretical'. On the practical side, such equation, according to Wiredu, would amount to being "content with the mere narration of the ideas Africans lived by as an adequate fulfillment of the philosopher's task in contemporary Africa." 32 From the theoretical angle, "it would deny Africans the opportunity of engaging fruitfully in the activity of modern philosophizing." 33

But the hostilities against ethnophilosophy in particular and traditional African philosophy in general by the analytic group is unwarranted because their views will definitely hurt Africa by robbing it, according to Barry Hallen of engagement in "a positive and fruitful relationship between Africa's indigenous intellectual heritage and technical systematic academic (Western) philosophy". ${ }^{34}$ One aspect of their grouse (analytic group) with traditional African philosophy is simply that it is largely oral and unwritten. In other words, "its various aspects have usually been transmitted from generation to generation by word of mouth." 35 However some scholars have shown that proverbs, myths, folklores etc, are important vehicles for the transmission of traditional thought and as 'sources of traditional conceptions and ideas, whether metaphysical, epistemological, ethical etc." 36

By advocating the method of science and technology as the basis of social development by the analytic African philosophers, they were uncompromising in calling for a break or total destruction of "traditional idols" and other heritage resources. But it is fruitless to pursue this project because 'the survival of the past in contemporary Africa cannot be eliminated by fiat. In the views of some scholars, particularly J. F. Ade-Ajayi,

...development is not simply an activity in which the old is replaced by the new in a mechanical manner. Rather, it is a process of social reconstruction in which the past survives in the present, though in a modified form... ${ }^{37}$ 
Based on the insight offered by the doyen of African historiography, Ade-Ajayi, we make bold to say that the views of the analytical African philosophers are unilluminating and therefore does not serve as adequate critique of ethnophilosophy.

The interest and my pre-occupation in this essay is to show that the attack on ethnophilosophy and the rejection of traditional African thought is misguided. This is because ethnophilosophy is still a fruitful discourse in contemporary Africa. Apart from promoting some aspects of our positive culture, also serves as a basis for promoting indigenous knowledge, which is "a paradigm shift from the mechanistic top-down models primarily concerned with economic development towards dynamic participatory approaches concerned with all facets of human development." In other words, the utilization of "indigenous institutions and culture in effecting more positive governance and development emphasizing participatory processes' at the socio-political and economic layers of the society is the interest of ethnophilosophers in postcolonial Africa.

\section{Conclusion}

Let us reiterate the thrust of our argument in this essay by saying that it is still worthwhile to study ethnophilosophy and traditional African philosophy because of their potentials for assisting Africa to overcome some of her development challenges.

\section{References}

Pauline J. Hountondji, African Philosophy Myth and Reality. London: Hutchinson University Library for Africa, 1983. 51-52.

Ibid. 52.

Ibid. 34.

Barry Hallen. African Philosophy, the Analytic Approach. Trenton: Africa World Press, Inc., 2006. 107-108. 
Pauline J. Hountondji, African Philosophy Myth and Realit. London: Hutchinson University Library for Africa, 1983. 82-83.

Ibid. 53.

Rush, E. A. The Ways of Knowing and Thinking. Lesotho: National University of Lesotho, 1977.

Wasi Wiredu. “On Defining African Philosophy” in Tsenay Serequeberhan (ed.) African Philosophy: The Essential Readings, New York: Paragon House, 1991. 87.

Anyanwu, K. C. The African Experience in the American Market Place, New York: Exposition Press, 1983. 60.

Abraham, W. E. The Mind of Africa Chicago: University of Chicago Press, 1962.

Olabiyi Yai, C.F. "Theory and Practice in African Philosophy: The Poverty of Speculative Philosophy" in Second Order, An African Journal of Philosophy vol. vi, No.2 (July 1977): 320.

Ibid. 11.

Mclean, Cf. George F. "Person as Essentially Cultural: From Individual Self-Interest to Cultural Traditions" in William Sweet et al. (eds.) The Dialogue of Cultural Traditions: A Global Perspective Washington DC: The Council for Research in Values and Philosophy, 2008. 23.

Anyanwu, K. C. "The Problem of method in African Philosophy" in C.S. Momoh (ed.) The substance of African Philosophy Nigeria: African Philosophy Projects Publishers, 1989. 140.

Guthrie, W. K. C. The Greek Philosophies: From Thales to Aristotle London: Methuen, 1967.

Russell, Bertrand. A History of Western Philosophy. 2nd Edition New York: Simon and Schuster, 1965. 174. 
Williams, Michael. Groundless Beliefs: An Essay on the Possibility of Epistemology. New Haven: Yale University Press, 1977. 8.

These Points appear in to Hamlyn, D.W. The Theory of Knowledge. London: The Macmillan Press, 1970. 4.

Barry Hallen and J. O. Sodipo, Knowledge, Belief and Witchcraft: Analytic Experiments in African Philosophy. London: Ethnographica Ltd., 1986. 8.

Price, H. H. Belief, London: George Allen and Union, 1969. 42.

For an Illuminating Account of the different senses of the verb 'to know', see Ayer, A.J. The Problem of Knowledge, Harmondsworth: Penguin Book, 1956. 8.

These points appear Oladipo, O.T. Knowledge as Justified Belief. An Unpublished M. A. project, University of Ibdan, 1984. 3-4.

Copleston, F. C. Philosophies and Cultures, Oxford: Oxford University Press, 1980. 12-12.

Claude Sumner. Classical Ethiopian Philosophy. Los Angeles: Adey Publishing Co., 1994. 17.

Masolo, D. A. African Philosophy in Search of Identity. Indiana: Indiana University Press, 1994. 59.

Claude Sumner. Classical Ethiopian Philosophy. 17.

Hountondji, Paulin J. African Philosophy Myth and Reality. 5662.

Presbey, Gail M. 'Broad' and 'Strict' Distinctions Proposed by Claude Sumner Regarding Ethiopian and African Philosophy in Claude Sumner and Samuel W. Yohannes (eds.) Perspectives in African Philosophy: An Anthology on Problematics of an African Philosophy: Twenty Years After (1996), Addis Ababa: University Printing Press, 2002. 78.

Kwasi Wiredu. "African Philosophical Tradition: A case Study of the Akan". The Philosophical Forum: A Quarterly Vol. 24, Nos. 1-3, (1992-93): 1. 
Olusegun Oladipo. Philosophy and the African Experience. The Contributions of Wiredu, Ibadan: Hope Publications, 1996. 14-15.

Barry Hallen. African Philosophy: The Analytic Approach. 106.

Ali. Mazrui, "The Written Word and Collective Identity" in east Africa Journal vol. 9 No.5, (1972): 3.

Kwame Gyekye. "The Philosophical Relevance of Akan Proverbs" in Second Order: An African Journal of Philosophy, Vol. iv, No.2. (July 1975): 45-53; See also D.N. Kaphagawani and H.F. Chidani Modzi, Chewa "Cultural Ideas and Systems of Thought as Determined by Proverbs: A Preliminary Analysis" in Journal of Social Sciences, vol. 10 (1983)100-110.

Ade Ajayi, J. F. "The Past in the Present: The Factor of Tradition in Development" National Merit Award Lecture delivered at Lagos in (December, 1990): 1-10.

Ibid. 10. 